\title{
Factors Affecting the Performance of Financial Administration Officials of Regional Apparatus Organizations at the Government of Medan
}

\author{
Cristian Hartanto ${ }^{1}$, Iskandar Muda ${ }^{1}$, Chandra Situmeang1 \\ ${ }^{1}$ Department of Accounting, Faculty of Economics and Business at Universitas Sumatera Utara, Indonesia \\ Corresponding Author: Cristian Hartanto
}

DOI: https://doi.org/10.52403/ijrr.20220211

\begin{abstract}
Research on the factors that affect the performance of officials performance in the government sector has been widely carried out. However, there are still relatively few studies that examine the factors that affect the performance of financial administration officials in the local government environment, and the research results are still varied and inconsistent. The purpose of this study was to find empirical evidence whether there is an influence on the quality of human resources, communication, supporting facilities, organizational commitment, and budget refocusing on the performance of financial administration officials of regional apparatus organizations at the government of Medan.

The population of this research is the financial administration officials of the regional apparatus organizations in the city of Medan. The unit of analysis is a senior official who works as a financial administrator. Data was collected using a questionnaire which was delivered directly by the author. Before testing the hypothesis with multiple regression analysis, the data quality test and classical assumption test were first carried out.

The results showed that simultaneously the quality of human resources, communication, supporting facilities, organizational commitment, and budget refocusing had a significant effect on the performance of financial administration officials of regional organizations in the regional government of Medan city. While partially organizational commitment and budget refocusing do not significantly affect the performance of financial
\end{abstract}

administration officials of regional organizations.

Keywords: quality of human resources, communication, supporting facilities, organizational commitment, budget refocusing, the performance of financial administration officials of regional work units.

\section{INTRODUCTION}

Regional financial management is a whole activity that includes planning, budgeting, implementation, administration, reporting, accountability, and supervision of regional finances. Regional finances are all regional rights and obligations in administering the regional government, which can be valued in money and all forms of wealth that can be used as regional property in connection with the rights and obligations of the region. Apart from being regulated by government regulations, regional finances also follow Ministerial regulations. Regional finances also follow the State Revenue and Expenditure Budget Law, stipulated every year. Each region's Regional Revenue and Expenditure Budgets are synchronized and managed systematically.

Effective public financial management is fundamental to economic growth. As the population grows, resources become scarce, or the economy grows more complex, the importance of public financial management increases. Implementing an effective regional financial management 
system is the responsibility of the local government to the community and taxpayers. The regional financial management system must be utilized to maintain and increase the prosperity of the people.

According to Mardiasmo (2002), the principles of regional financial management needed to control regional financial policies include accountability, value for money, honesty in managing public finances, transparency, and control. Article 4 of the Government Regulation of the Republic of Indonesia Number 58 of 2005 concerning Regional Financial Management states that regional finances are managed in an orderly manner, obeying laws and regulations, efficient, economical, effective, transparent, and responsible with due observance of the principles of justice, propriety, and benefits for the community. Furthermore, implemented in an integrated system embodied in the Regional Revenue and Expenditure Budget, which is annually stipulated by regional regulations. Effective and efficient regional financial management is implemented through good governance with 3 main pillars: transparency, accountability, and participation.

In the context of transparent and accountable regional financial management, local governments are required to submit accountability in financial reports prepared following Government Accounting Standards. The Supreme Audit Agency examines the financial statements, then reports to the public through the Regional House of Representatives. Regarding regional financial accountability, the Medan City Government has again received an Unqualified Opinion (UO) from the Supreme Audit Agency of the Republic of Indonesia, Representative of the Province of North Sumatra for the Medan City Government Financial Report for the 2014 Fiscal Year. This UO opinion is the fourth time in a row since 2011. The opinion of the PAPs indicates that the financial management performance of the Medan City Government is good even though the
UO is still followed by an explanatory paragraph related to the issue of disputed land assets with third parties in 28 locations worth around Rp. 101 billion. Seven locations are in court proceedings, while the other 21 are still in ordinary disputes (BPK, 2015).

State/regional financial management in Indonesia has undergone many changes or improvements in line with the spirit of government financial management reform to achieve the success of regional autonomy. It is marked by the issuance of a package of laws and regulations in state finance and their derivative regulations, which have also undergone many revisions and improvements. Several regulations related to the implementation of regional autonomy that has been issued are a package of laws in the field of state finance, namely Law No. 17 of 2003 concerning State Finance, Law no. 1 of 2004 concerning the State Treasury, and Law no. 15 of 2004 concerning Audit of State Finance Management and Responsibility.

In order to implement the legislation in the field of state finance, various implementing regulations have been issued in the form of Government Regulations. Among other things, Government Regulations No. 20 of 2004 concerning the Government Work Plan, Government Regulations No. 21 of 2004 concerning Work Plans and Budgets of State Ministries/Institutions, and Government Regulation No. 24 of 2004 concerning Government Accounting Standards. Specifically, concerning regional financial management, Government Regulation No. 58 of 2005 concerning Regional Financial Management was issued.

As a follow-up to Government Regulation No. 58 of 2005, the Minister of Home Affairs has issued Regulation of the Minister of Home Affairs No. 13 of 2006 concerning Guidelines for Regional Financial Management. The latest has been revised by Minister of Home Affairs Regulation No. 58 of 2005. 59/2007 concerning Amendments to Minister of Home Affairs Regulation No. 13/2006 
concerning Guidelines for Regional Financial Management. This regulation regulates new regional financial management guidelines following state/regional financial governance reform. This regulation's basic change is shifting the ordinancering function from the Finance Agency/section/bureau to each Regional Apparatus Work Unit. The Regional Apparatus Work Unit, as an accounting entity, is obliged to make financial reports and confirm that the expenditure treasurer is a functional official. Therefore, each expenditure treasurer must have special expertise in the treasury field and be proven by a certificate of expertise from the authorized institution to organize Expenditure Treasurer Certification Training.

The implementation of regulations has been carried out in stages within the Medan municipal government. However, several indications indicate that the regulations have not been implemented optimally and thoroughly. It is evidenced by the many allegations of corruption that occurred in the Medan city government. For several periods, the mayor of Medan has always been implicated in corruption and has often made national news. It raises questions about the management of the Medan city government's financial administration, which is considered fragile and prone to opportunities for corruption. Many factors are considered to be the cause of the fragility of this financial management, especially in the field of competence possessed by the financial administration officials of the city of Medan. In addition, the absorption of the budget in the city of Medan is quite low. Towards the end of 2019, the budget absorption of the Medan City Government, as of January-October 2019, was realized only $47 \%$ of the 2019 Local Government Budget of Rp 6.3 trillion.

According to Mahsun (2009), the public sector can be understood as everything related to the public interest and goods and services to the public, paid for through taxes or other state revenues regulated by law. Within the framework of understanding the public sector, the intended public goods are physical goods and contain non-physical meanings, namely public services. According to Campbell (1990), the factors that affect performance can be expressed in the form of the functional relationship between performance and performance attributes as follows:

Performance $=\mathbf{f}$ (knowledge, skills, motivation, role perception)

Where knowledge is the knowledge possessed by employees, skill refers to the ability of employees to do work, motivation is encouragement and enthusiasm to do work, and role perception shows the role of individuals in doing work. To determine organizational performance, each organization must have success criteria in the form of certain targets to be achieved. The level of achievement of these targets is based on a certain concept that has been tested for validity in measuring the performance of an organization.

Performance measurement can be concluded as a method or tool used to assess the achievement of implementing activities based on strategic plans so that organizational progress can be known and improve the quality of decision-making and accountability. Regional Apparatus Organizational performance measurement is carried out in local government organizations to assess how well the Regional Apparatus Organizational performs the main tasks and functions assigned to it during a certain period. Regional Apparatus Organizational performance measurement is a form of vertical accountability, namely evaluating the performance of subordinates by their superiors and as a material for horizontal accountability of local governments, namely to the community for the mandate given to them. In carrying out the process of managing regional finances, each Regional Apparatus Working Unit following the provisions of Minister of Home Affairs 
Regulation No. 13 of 2006 is said to be a budget user carrying out tasks, among others, from the process of preparing the Local Government Budget, implementing and administering expenditures, implementing and structuring revenues, accounting and reporting to changes in the Local Government Budget.

The Regional Apparatus

Organizational in the regional financial management cycle is at the third level in the regional financial management and accountability system, directly responsible to the Regional Head (Governor) through the Regional Financial Management Officer. The Head of the Regional Apparatus Organizational also supervises the Financial Administration Officer, the Technical Implementation Officer, the Revenue Treasurer, and the Regional Apparatus Organizational Expenditure Treasurer. Based on the structure and responsibilities, it can be seen that the regional work units have very important participation and role in the management of regional finances.

Edward (1992) states that local financial management can be done well if local governments can clearly define the objectives of financial management. It indicates that if the local government can clearly define or formulate the objectives of regional financial management, then the policy regarding the allocation of regional resources for the public interest can be achieved.

This study will discuss several factors that affect the performance of financial administration officials of regional work units, namely the quality of human resources, communication, supporting facilities, organizational commitment, and budget refocusing.

According to Wiley (2002), Azhar (2007) defines that HR as an individual as the main supporting pillar and the organization's driving force to realize the vision and mission and the goals of the organization. HR is a very important organizational element. Therefore it must be ensured that HR must be managed as well as possible in order to be able to contribute optimally in efforts to achieve organizational goals.

Agencies/institutions in the context of good financial management must have quality human resources supported by an accounting education background, often attend education and training, and have experience in the financial sector. Applying the accrual basis requires human resources who understand accounting well, including the characteristics of the transactions that occur and their effects on accounts and financial statements. Failure to understand and apply to account impacts errors in the financial statements made, and the report does not comply with the standards set by the government (Matindas, 2002).

In government circles, the role of employees, both individually and in groups, is very important and decisive. Employees as assets and the main element in the organization play a very decisive role in achieving organizational goals. All elements of organizational resources will not function without being handled by humans, who are the main movers of the organization.

According to Arep and Tanjung (2004), communication flows freely from top to bottom or vice versa. In managing regional finances in a Regional Apparatus Organizational, good and smooth communication between Budget Users and their subordinates or vice versa is needed in equalizing perceptions to formulate and formulate and implement the work plans to be achieved by Regional Apparatus Organizational. Because even though the results of someone's thinking, both leaders and subordinates, will be meaningless if they are not stated and communicated properly. Leaders not only can make commitments or decisions, but must be translated into ideas, initiatives, initiatives, creativity, opinions, suggestions, orders, and others of that kind through good communication. Therefore, making decisions will lose its meaning without communicating them (Nawawi and Martini, 
2004). With good communication, all components in the Regional Apparatus Organizational can systematically work in the same direction, namely to increase agency productivity (Suranto, 2005). Suppose there is a misunderstanding within the Regional Apparatus Organizational, especially in managing regional finances. In that case, it will have a negative impact that will adversely affect the performance of the Regional Apparatus Organizational.

Communication skills for a leader can minimize or even eliminate conflicts between personal interests and organizational interests (Effendi, 1989). For this reason, good and smooth communication is always fostered in government agencies by involving officials and staff in formulating and deciding important decisions or matters within the agency, especially regarding the management of regional finances in the Regional Apparatus Work Unit.

The supporting facilities referred to in this study are the availability of supporting devices that will assist the performance of the Regional Apparatus Organizational in the context of managing regional finances to support the implementation of tasks such as the availability of computer equipment and software related to the needs of the Regional Apparatus Organizational. Based on Minister of Home Affairs Regulation Number 13 of 2006 article 225, to facilitate the implementation of the bookkeeping of the expenditure treasurer, it is allowed to use application software. However, the consequence is that the expenditure treasurer must be able and proficient in operating a computer and understand the application of regional financial administration procedures and bookkeeping of the expenditure treasurer.

The government accounting system is a series of manual or computerized procedures ranging from data collection, recording, summarizing, and reporting financial position and government financial operations. Based on this definition, the local government's financial accounting system to run effectively requires supporting facilities, hardware, and software.

According to Mowday et al. (1979), in Darma (2004), Organizational commitment is a strong belief and support for the values and goals that the organization wants to achieve. With a strong commitment, it will be possible for a person to spend additional physical, mental, and spiritual resources that can be obtained. On the contrary, big jobs will be difficult without commitment. According to Mayer et al. (1993), cited by Arifuddin et al. (2002), there are three components of organizational commitment, namely;

a. Effective commitment occurs when employees want to be part of the organization because of an emotional attachment;

b. Continuance commitment occurs when employees remain in an organization because they need a salary and other benefits or because the employee cannot find another job;

c. Normative commitment (normative commitment) arises from employee values. Employees stay as members of the organization because there is an awareness committed to the organization must be done.

Budget refocusing is to refocus or refocus the budget for activities that were not previously budgeted through budget changes. The purpose of budget refocusing is to reallocate the budget.

Following the provisions of the Joint Decree of the Minister of Home Affairs and the Minister of Finance Number 119/2813/SJ and Number 177/KMK.07/2020 concerning Acceleration of Adjustment of the 2020 Local Government Budget in the Context of Handling Corona Virus Disease 2019 (Covid-19), as well as Securing Public Purchasing Power and the National Economy and Minister of Finance Regulation Number 35/PMK.07/2020 concerning Management of Transfers to 
Regions and Village Funds for the Fiscal Year 2020 in the context of Handling the Corona Virus Disease 2019 (Covid-19) Pandemic and Facing Threats That Endanger the National Economy instructs the Regional Governments to adjust Local Own-source Revenue by adjusting the Potential of Regional Taxes and Regional Levies as a result of the decline in economic activity.

Local governments are also asked to adjust Transfer Funds from the Central Government based on the Details of Allocation of Transfers to Regions, and Village Funds stipulated in Minister of Finance regulation Number 35/PMK.07/2020. In the provisions mentioned above, the Regional Government must cut goods/services expenditures by at least $50 \%$, reduce capital expenditures by at least $50 \%$ and adjust personnel expenditures. The difference between the Budget Result from the Adjustment of Regional Revenue and Expenditure Targets is used to fund:

a. Spending on Health and other matters related to health in the context of preventing and handling the COVID-19 pandemic;

b. Provision of a Social Safety Net; and

c. Handling Economic Impacts is primarily to keep the local business world alive.

Based on the phenomena and results of the research above, the researchers are motivated to conduct further research on the performance of local government organizations with the title "Factors Affecting the Performance of Financial Administration Officials of Regional Apparatus Organizations at the Government of Medan."

\section{PREVIOUS RESEARCH REVIEW}

Ririn and Mardiasmo (2004) conducted a study on the performance of local government agencies in Yogyakarta. The results of their research show that organizational commitment, decentralized structure, and participation in budgeting affect the performance of government agency managers.

Azhar (2007) has researched the factors that influence the success of the implementation of Minister of Home Affairs Regulation 13 of 2006 in the Banda Aceh City Government, with the independent variables being commitment, human resources, supporting tools, and regulations, while the dependent variable is the success of the implementation of Minister of Home Affairs Regulation 13 of 2006 The results of this study conclude that simultaneously commitment, human resources, supporting tools and regulations have a significant influence on the success of the implementation of Minister of Home Affairs Regulation No. 13 of 2006. Meanwhile, partial regulations do not significantly affect implementing Minister of Home Affairs Regulation 13 of 2006.

Tuasikal (2007) conducted a study on "The Influence of Understanding Regional Financial Management Accounting Systems on Regional Apparatus Organizational Performance (Study in Central Maluku Regency in Maluku Province)," with the independent variable being the understanding of the regional financial accounting system and regional financial management, while the dependent variable is the performance of the Regional Apparatus Organization unit. This study concludes that both simultaneous and partial understanding of accounting systems and financial management affects the performance of Regional Apparatus Organizations, meaning that if regional financial management is managed according to applicable mechanisms and is supported by increased understanding of regional financial accounting, it can encourage the performance of each Apparatus Organization Area.

Suhartono et al. (2007) conducted a study on "The Influence of Clarity of Budget Targets on Budgetary Slacks of Local Government Agencies with Organizational Commitment as Moderating," with the independent variable 
being the clarity of budget targets, the dependent variable is the budgetary slack of local government agencies and organizational commitment as a moderating variable. The study results conclude that the clarity of budget targets has a significant negative effect on the budgetary slack of local government agencies. The clarity of budget targets will reduce the occurrence of budgetary slack.

Haykal (2007) has analyzed "The role and function of Regional Apparatus Organizational in regional financial management and their effect on performance (Case study in East Aceh Regency Government)." Understanding Regional Financial Management Accounting Systems on Regional Apparatus Organizational Performance. The independent variables are budget planning, preparation, execution, and reporting, while the dependent variable is Regional Apparatus Organizational performance. This study concludes that in the simultaneous testing of budget planning, budgeting, budget execution, and budget reporting, the significant effect on the performance of the Regional Apparatus Organizational in the East Aceh Regency Government, while the partial test can be seen that only the budgeting variables significantly affect the performance of the Regional Apparatus Organizational. The variables of budget planning, budget execution, and budget reporting have no significant effect on Regional Apparatus Organizational performance.

Yusriati (2008) examined the effect of implementing performance-based budgeting on Regional Apparatus Organizational performance in the Mandailing Natal District Government, while the dependent variable was Regional Apparatus Organizational performance and the independent variable was performancebased budgeting. Mandailing Natal is still relatively low, Regional Apparatus Organizational performance on average is also considered relatively good, namely in the economic category. The results show implementing performance-based budgeting on Regional Apparatus Organizational performance. The suggestion for further researchers is to develop or improve the research questionnaire because the questionnaire used by the researcher is selfdesigned.

Warisno (2009) conducted a study on "Factors Affecting the Performance of Regional Work Units in the Jambi Provincial Government. The independent variables are Human Resources Quality, Communication, Supporting Facilities, and Organizational Commitment, with OPD performance as the dependent variable. The results showed that the quality of human resources, communication, supporting facilities, and organizational commitment simultaneously had a significant positive effect on Regional Apparatus Organizational performance. The results of this study support Azhar's research, which concludes that simultaneously organizational commitment, human resources, supporting devices have a significant influence on the success of the implementation of Minister of Home Affairs Regulation No. 13 of 2006. However, only the quality of human resources and communication partially has a significant positive effect on OPD performance. In contrast, the variables of supporting facilities and organizational commitment do not significantly affect the performance of OPD. This study rejects the results of Azhar's research, which concludes that partially organizational commitment and supporting devices have a significant influence on the successful implementation of Minister of Home Affairs Regulation No. 13 of 2006.

\section{Framework}

Following the description of the background of the problem, literature review, and previous research, a conceptual research framework is prepared as follows: 


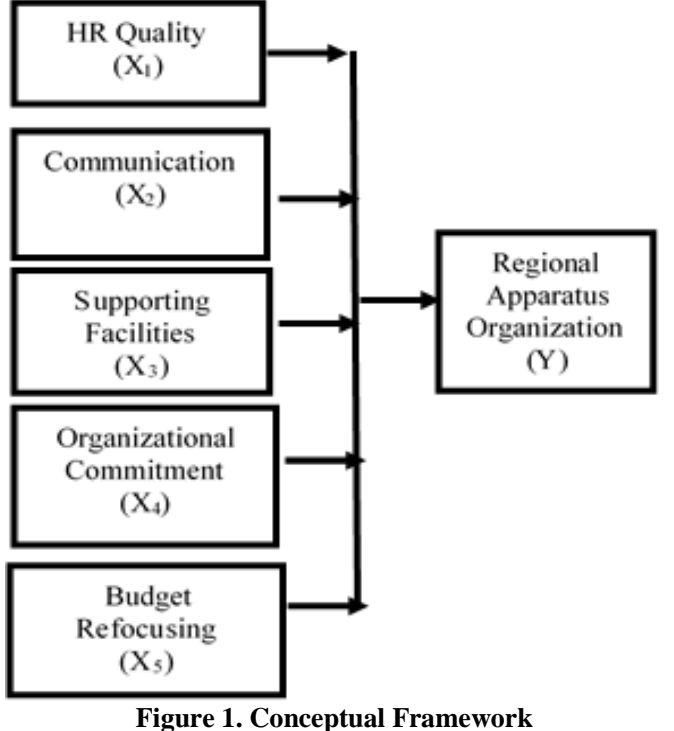

H1: The quality of human resources affects the performance of the financial administration officials of regional organizations.

$\mathrm{H} 2$ : Communication affects the performance of financial administration officials of regional apparatus organizations.

H3: Supporting facilities affect the performance of financial administration officials of regional apparatus organizations. H4: Organizational commitment affects the performance of financial administration officials of regional organizations.

H5: Budget refocusing affects the performance of financial administration officials of regional apparatus organizations. H6: The quality of human resources, communication, supporting facilities, organizational commitment, and budget refocusing affect the performance of financial administration officials of regional organizations simultaneously.

\section{RESEARCH METHODS}

This type of research is causal associative research to determine the factors of whether the Quality of Human Resources (HR), Communication, Supporting Facilities, Organizational Commitment, and Budget Refocussing as an independent variable on the performance of financial administration officials of regional organizations as the dependent variable in the city government environment Medan.
The causal associative study analyzes the relationship between one variable and another to determine how one affects other variables (Erlina, 2011). The data collection technique used is a questionnaire (questionnaire). The data analysis method used in this study is a statistical analysis method using the SPSS 21 application. Data analysis performs by testing standard assumptions and testing hypotheses.

The population in this study is the financial manager at the Regional Apparatus Organizational equivalent to Echelon II in the Medan City Government. There are 3 financial managers in each Regional Apparatus Organizational of the Medan City Government with details of positions as Financial Administration Officer, Technical Implementation Officer, and Expenditure Treasurer. In this study, the number of Regional Apparatus Organizational equivalent to Echelon II was 35 , so that the total population in this study was 105 people. The sampling method used is a saturated sample technique (census), a sampling technique that makes all members of the population samples (Sugiyono, 2014). The sample in this study was 90 people.

\section{RESULT AND DISCUSSION Data analysis}

\section{Testing Data Validity and Reliability}

Before testing the data, both for the description of the research data and for testing classical assumptions and hypotheses, it is necessary to test the validity and reliability of the data. This test needs to be done because the type of research data is primary data.

\section{Validity Test}

Testing the validity of the instrument using SPSS software. The validity value can be seen in the Corrected item-total Correlation column. If the correlation number obtained is greater than the critical number ( $\mathrm{r}$ count $>\mathrm{r}$ table), the instrument is valid. Based on the validity test results, it can be concluded that not all question items to measure each research variable are 
Cristian Hartanto et.al. Factors affecting the performance of financial administration officials of regional apparatus organizations at the government of Medan.

declared valid. It can be seen that not all $r$ the $r$ table for a sample of 105 is 0.19 , as count is greater than $r$ table. The value of can be described in table 1 .

\begin{tabular}{|c|c|c|c|c|}
\hline Variables & Instrument Items & $r$ count & $r$ table & Note \\
\hline \multirow{15}{*}{ Regional Apparatus Organization (Y) } & RAOP1 & 0,132 & 0,190 & Invalid \\
\hline & RAOP2 & 0,421 & 0,190 & Valid \\
\hline & RAOP3 & 0,313 & 0,190 & Valid \\
\hline & RAOP4 & 0,287 & 0,190 & Invalid \\
\hline & RAOP5 & 0,177 & 0,190 & Valid \\
\hline & RAOP6 & 0,334 & 0,190 & Valid \\
\hline & RAOP7 & 0,757 & 0,190 & Valid \\
\hline & RAOP8 & 0,593 & 0,190 & Valid \\
\hline & RAOP9 & 0,656 & 0,190 & Valid \\
\hline & RAOP10 & 0,237 & 0,190 & Valid \\
\hline & RAOP11 & 0,248 & 0,190 & Valid \\
\hline & RAOP12 & 0,377 & 0,190 & Valid \\
\hline & RAOP13 & 0,757 & 0,190 & Valid \\
\hline & RAOP14 & 0,378 & 0,190 & Valid \\
\hline & RAOP15 & 0,302 & 0,190 & Invalid \\
\hline \multirow{10}{*}{$\begin{array}{l}\text { HR Quality } \\
\text { (X1) }\end{array}$} & HRQ1 & 0,303 & 0,190 & Valid \\
\hline & HRQ2 & 0,578 & 0,190 & Valid \\
\hline & HRQ3 & 0,520 & 0,190 & Valid \\
\hline & HRQ4 & 0,506 & 0,190 & Valid \\
\hline & HRQ5 & 0,494 & 0,190 & Valid \\
\hline & HRQ6 & 0,510 & 0,190 & Valid \\
\hline & HRQ7 & 0,493 & 0,190 & Valid \\
\hline & HRQ8 & 0,487 & 0,190 & Valid \\
\hline & HRQ9 & 0,467 & 0,190 & Valid \\
\hline & HRQ10 & 0,369 & 0,190 & Valid \\
\hline \multirow{15}{*}{$\begin{array}{l}\text { Communication } \\
\text { (X2) }\end{array}$} & $\mathrm{C} 1$ & 0,378 & 0,190 & Valid \\
\hline & $\mathrm{C} 2$ & 0,260 & 0,190 & Valid \\
\hline & $\mathrm{C} 3$ & 0,250 & 0,190 & Valid \\
\hline & $\mathrm{C} 4$ & 0,375 & 0,190 & Valid \\
\hline & $\mathrm{C} 5$ & 0,158 & 0,190 & Invalid \\
\hline & C6 & 0,328 & 0,190 & Valid \\
\hline & $\mathrm{C} 7$ & 0,417 & 0,190 & Valid \\
\hline & $\mathrm{C} 8$ & 0.466 & 0,190 & Valid \\
\hline & C9 & 0,416 & 0,190 & Valid \\
\hline & $\mathrm{C} 10$ & 0,309 & 0,190 & Valid \\
\hline & C11 & 0,326 & 0,190 & Valid \\
\hline & $\mathrm{C} 12$ & 0,383 & 0,190 & Valid \\
\hline & $\mathrm{C} 13$ & 0,457 & 0,190 & Valid \\
\hline & C14 & 0,213 & 0,190 & Valid \\
\hline & $\mathrm{C} 15$ & 0,302 & 0,190 & Valid \\
\hline \multirow[t]{5}{*}{ Supporting Facilities (X3) } & SF1 & 0,473 & 0,190 & Valid \\
\hline & SF2 & 0,566 & 0,190 & Valid \\
\hline & SF3 & 0,649 & 0,190 & Valid \\
\hline & SF4 & 0,648 & 0,190 & Valid \\
\hline & $\begin{array}{l}\text { SF5 } \\
\end{array}$ & 0,539 & 0,190 & Valid \\
\hline \multirow[t]{15}{*}{ Organizational Commitment (X4) } & $\mathrm{OC} 1$ & 0,274 & 0,190 & Valid \\
\hline & OC2 & 0,383 & 0,190 & Valid \\
\hline & OC3 & 0,373 & 0,190 & Valid \\
\hline & OC4 & 0,192 & 0,190 & Valid \\
\hline & OC5 & 0,376 & 0,190 & Valid \\
\hline & OC6 & 0,313 & 0,190 & Valid \\
\hline & OC7 & 0,128 & 0,190 & Invalid \\
\hline & OC8 & 0,509 & 0,190 & Valid \\
\hline & OC9 & 0,497 & 0,190 & Valid \\
\hline & OC10 & 0,169 & 0,190 & Invalid \\
\hline & OC11 & 0,109 & 0,190 & Invalid \\
\hline & OC12 & 0,051 & 0,190 & Invalid \\
\hline & $\mathrm{OC} 13$ & 0,376 & 0,190 & Valid \\
\hline & OC14 & 0,294 & 0,190 & Valid \\
\hline & OC15 & 0,196 & 0,190 & Valid \\
\hline \multirow{5}{*}{$\begin{array}{l}\text { Budget } \\
\text { Refocussing } \\
\text { (X5) }\end{array}$} & $\mathrm{R} 1$ & 0,586 & 0,190 & Valid \\
\hline & $\mathrm{R} 2$ & 0,507 & 0,190 & Valid \\
\hline & R3 & 0,644 & 0,190 & Valid \\
\hline & $\mathrm{R} 4$ & 0,584 & 0,190 & Valid \\
\hline & R5 & 0,522 & 0,190 & Valid \\
\hline
\end{tabular}


Several items are not valid based on the validity test results for the performance variables of Regional Apparatus Organizational, Communication, and Organizational Commitment. There are two invalid question items for the Regional Apparatus Organizational performance variable, namely question items 1 and 5 . One invalid question item in the communication variable is question number 5. In contrast, the organizational commitment variable found four invalid question items: question numbers $7,10,11$, and 12. Therefore, these items were not included as question items to process further data.
For the variables of HR quality, supporting facilities, and budget refocusing, it can be concluded that all items for each question are valid.

\section{Reliability Test}

After testing the validity, the next step is to test the reliability of the data by looking at the value of Cronbach's alpha. If the value of Cronbach's alpha is greater than 0.6 , then the research questionnaire is declared reliable. The data testing results show that the value of Cronbach's alpha is greater than 0.6. It shows that all research data is stated to be reliable.

Table 2. Variable Reliability Test

\begin{tabular}{|l|l|l|l|}
\hline Variable & Alpha Cronbach's & Reliability Limit & Note \\
\hline Regional Apparatus Organization (Y) & 0,635 & 0,6 & Reliable \\
\hline HR Quality (X1) & 0,616 & 0,6 & Reliable \\
\hline Communication (X2) & 0,639 & 0,6 & Reliable \\
\hline Supporting Facilities (X3) & 0,682 & 0,6 & Reliable \\
\hline Organizational Commitment (X4) & 0,698 & 0,6 & Reliable \\
\hline Budget Refocussing (X5) & 0,665 & 0,6 & Reliable \\
\hline
\end{tabular}

\section{Description of Research Results}

\begin{tabular}{l} 
Table 3. Description of Statistics \\
\begin{tabular}{|l|l|l|l|l|l|}
\hline & N & Min & Max & Mean & Std. Dev \\
\hline RAOP (Y) & 105 & 3,00 & 4,20 & 3,5854 &, 27704 \\
\hline HR Quality (X1) & 105 & 3,10 & 4,50 & 3,7752 &, 33849 \\
\hline Communications (X2) & 105 & 3,13 & 4,20 & 3,6749 &, 23709 \\
\hline Supporting Facilities (X3) & 105 & 3,20 & 4,80 & 4,0762 &, 39844 \\
\hline Organizational Commitment (X4) & 105 & 3,20 & 4,13 & 3,6851 &, 19403 \\
\hline Budget Refocussing (X5) & 105 & 3,60 & 4,80 & 4,1810 &, 35249 \\
\hline Valid N (listwise) & 105 & & & & \\
\hline
\end{tabular} \\
\hline
\end{tabular}

The average value of Regional Apparatus Organizational performance is 3.58, which indicates that the performance of Regional Apparatus Organizational in Medan City Government is above average. The average value of HR quality is 3.77 , indicating that the average HR quality is above the average. Communication with an average value of 3.67 indicates that the average value of communication is above average. Supporting facilities with an average value of 4.07 indicates that the average value of supporting facilities is above the average. Organizational commitment with an average of 3.68 indicates that the respondents have a fairly high organizational commitment in managing regional finances. Budget refocusing with an average value of 4.18 indicates that the budget refocusing value is above the average.

\section{Classic Assumption Test Normality Test}

Based on the normality test results of the data using the Kolmogorov-Smirnov test and by looking at the graph test, it can be concluded that the data has a normal distribution. It can be seen by looking at the Kolmogorov Smirnov value of 0.595 with a significance level of 0.871 . If the significance of Kolmogorov Smirnov's value is greater than 0.05 , it can be stated that the data has a normal distribution. It is 
also supported by a graph that follows a diagonal line. The normality test graph can be seen in the following figure:

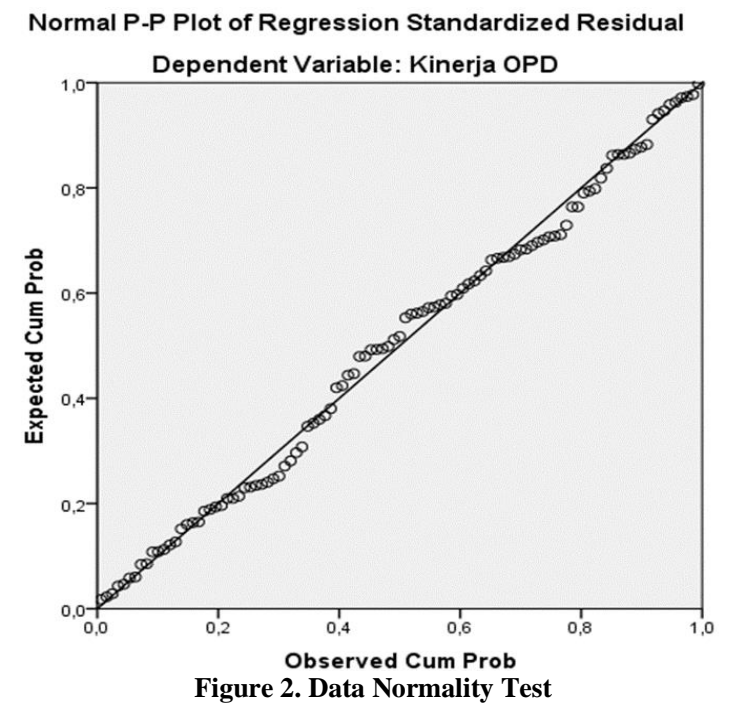

\section{Multicollinearity Test}

Based on the correlation test results between the independent variables, it can be seen that the correlation between these variables is relatively not high. No correlation exceeds 0.8 . It indicates that there is no multicollinearity problem between the independent variables. This test is supported by a relatively small VIF value, which is none greater than 5 .

Table 4. Multicollinearity Test Results

\begin{tabular}{|c|c|c|c|}
\hline \multirow{2}{*}{\multicolumn{2}{|c|}{ Model }} & \multicolumn{2}{|c|}{ Collinearity Statistics } \\
\hline & & Tolerance & VIF \\
\hline \multirow[t]{6}{*}{1} & (Constant) & & \\
\hline & $\mathrm{X} 1$ & ,442 & 2,264 \\
\hline & $\mathrm{X} 2$ &, 472 & 2,117 \\
\hline & X3 & ,388 & 2,577 \\
\hline & $\mathrm{X} 4$ & ,605 & 1,653 \\
\hline & $\mathrm{X} 5$ & ,684 & 1,461 \\
\hline \multicolumn{2}{|c|}{$\begin{array}{l}\text { a. Dependent } \\
\text { Performance }\end{array}$} & Regional & Organization \\
\hline
\end{tabular}

\section{Hypothesis Test}

Table 5. Hypothesis Testing Results

\begin{tabular}{|c|c|c|c|c|c|}
\hline \multirow{2}{*}{\multicolumn{2}{|c|}{ Model }} & \multirow{2}{*}{\multicolumn{2}{|c|}{ Unstandardized Coefficients }} & \multirow{2}{*}{$\begin{array}{l}\mathbf{t} \\
, 191\end{array}$} & \multirow{2}{*}{$\begin{array}{l}\text { Sig. } \\
, 849 \\
\end{array}$} \\
\hline & & & & & \\
\hline 1 & (Constant) & $\begin{array}{l}\mathrm{B} \\
, 061 \\
\end{array}$ & $\begin{array}{l}\text { Std. Error } \\
320\end{array}$ & & \\
\hline & HR Quality (X1) & ,334 & ,064 & 5,209 &, 000 \\
\hline & Communications (X2) & ,898 & ,088 & 10,156 &, 000 \\
\hline & Supporting Facilities (X3) &,- 260 &, 058 & $-4,483$ &, 000 \\
\hline & Organizational Commitment (X4) &, 019 & ,096 &, 195 &, 846 \\
\hline & Budget Refocussing (X5) &,- 011 & ,049 &,- 216 &, 830 \\
\hline \multicolumn{6}{|c|}{$\begin{array}{c}\text { Dependent Variable: } \text { Kinerja OPD } \\
R=0,856 \\
\text { Adjusted } R^{2}=0,718 \\
F=54,075 \\
\text { Sig. } F=0,000 \\
\text { Source: } \text { SPSS } 21(2021)\end{array}$} \\
\hline
\end{tabular}

\section{Coefficient of Determination (R2)}

The adjusted R2 value of 0.718 means that the independent variable of $71.8 \%$ can explain the dependent variable. In other words, $71.8 \%$ of changes in OPD performance can be explained by variables of human resource quality, communication, supporting facilities, organizational commitment, and budget refocusing. The remaining $28.2 \%$ is explained by other factors not included in this study.

\section{Simultaneous Test (F Test)}

From the ANOVA test or F test, it was found that $\mathrm{F}$ count with a significant level of 0.000 because the probability is $0.000<0.05$, the results of the regression model show that there is an effect of the quality of human resources, communication, supporting facilities, organizational commitment and budget refocusing on OPD performance simultaneously.

\section{Regression Analysis}

Based on the results of hypothesis testing that has been carried out, the research model is as follows:

\section{$\mathrm{Y}=0.61+0.334 \mathrm{X} 1+0.898 \mathrm{X} 2-0.260 \mathrm{X3}$} $+0.019 X 4-0.011 X 5+e$

The above equation shows that the coefficients of HR quality, communication, and organizational commitment show positive numbers. It means that the relationship between the variables of $\mathrm{HR}$ 
quality, communication, and organizational commitment with Regional Apparatus Organizational performance is positive. The higher the HR quality, communication, and organizational commitment variables, the higher the Regional Apparatus Organizational performance. Meanwhile, the supporting facilities and budget refocusing show negative numbers. It means that the relationship between supporting facilities and budget refocusing on Regional Apparatus Organizational performance is negative. The higher the supporting facilities and budget refocusing variables, the lower the Regional Apparatus Organizational performance and vice versa.

\section{Partial Test (t-Test)}

The effect of each independent variable is that the dependent variable can be seen from the t-count value and the significance of the t-count value partially. If the significance value of the $t$-count $<0.05$, it can be stated that there is an influence of the independent variable on the dependent variable.

Based on the results of testing the data in table 5, it can be stated that the variables of the quality of human resources, communication, and supporting facilities significantly influence the Regional Apparatus Organizational's performance. In contrast, the variables of organizational commitment and budget refocusing do not significantly affect the performance of the Regional Apparatus Organizational.

\section{CONCLUSION}

Based on the results of data analysis and research discussion, the following conclusions can be drawn:

1. The results showed that the quality of human resources, communication, supporting facilities, and organizational commitment simultaneously had a significant positive effect on Regional Apparatus Organizational performance. The results of this study support Azhar's research, which concludes that simultaneously organizational commitment, human resources, supporting devices have a significant influence on the successful implementation of Minister of Home Affairs Regulation No. 13 of 2006.

2. But partially, only the quality of human resources, communication, and supporting facilities have a significant positive effect on the performance of Regional Apparatus Organizational. In contrast, the variables of organizational commitment and budget refocusing do not significantly affect the performance of the Regional Apparatus Organizational. This study rejects the results of Azhar's research, which concludes that, partially, organizational commitment has a significant influence on the successful implementation of Minister of Home Affairs Regulation No. 13 of 2006.

\section{LIMITATIONS OF THE RESEARCH}

Because this study uses a research instrument in the form of a questionnaire, so there are still possible weaknesses encountered, such as inaccurate answers, respondents who answered carelessly, dishonestly, and questions that were incomplete or poorly understood by respondents and researchers who did not know whether the questionnaire was filled out by the respondent concerned.

\section{SUGGESTION}

Based on the conclusions of the research, the suggestions given are as follows:

1. It is advisable for further research to use direct observation or observation of the object or the experimental method as a substitute for the questionnaire method.

2. This research needs to be developed further to obtain stronger empirical results, namely by adding other variables that are thought to affect the performance of Regional Apparatus Organizational, such as Motivation Factors, Paternalistic Culture, and Resistant to Change. 
3. To Regional Apparatus Organizations and Regional Governments in the context of good regional financial management, please accept employees with accounting education backgrounds, and improve the quality of existing human resources by providing education and training in the field of finance and computers.

\section{Acknowledgement: None}

\section{Conflict of Interest: None}

\section{Source of Funding: None}

\section{REFERENCES}

1. Arep, Ishak dan Tanjung, Henri. 2004. Manajemen Motivasi. Cetakan kedua.Grasindo Jakarta.

2. Arifuddin, Anik, Sri dan Wahyudin, 2002, Analisis Pengaruh Komitmen Organisasi dan Keterlibatan Kerja Terhadap Hubungan Antara Etika Kerja Islam dengan Sikap Perubahan Organisasi (Studi Empiris Terhadap Dosen Akuntansi Pada Perguruan Tinggi Islam Swasta di Malang dan Makassar), Simposium Nasional Akuntansi, Semarang, 5 - 6 September.

3. Azhar, (2007), Faktor-faktor yang mempengaruhi Keberhasilan Penerapan Permendagri No.13 pada Pemerintah Kota Banda Aceh.Tesis. Program Pasca Sarjana USU : Medan

4. BPK RI, 2015. Laporan Hasil Pemeriksaan BPK atas LKPP Tahun 2014. Jakarta : BPK RI

5. Dharma. 2004. Manajemen Pemerintahan Indonesia. PT. Djaniatan. Jakarta

6. Edwar, J. Mazur, 1992. The Vision for Improving Federal Financial Management, The Government Accounting Journal. Vol. 41. No.3. fall.

7. Effendy, Onang Uchjana. 1989. Psikologi Manajemen dan Administrasi. Cetakan ketiga. Mandar Maju, Bandung.

8. Erlina. (2011). Metodologi Penelitian Bisnis untuk Akuntansi dan Manajemen. Medan; USU Press

9. Farida, Yusriati Nur, Yuli Prasetyo dan Eliada Herwiyati. 2010. Pengaruh Penerapan Corporate Governance Terhadap Timbulnya Earning Manajement dalam
Menilai Kinerja Keuangan pada Perusahaan perbankan di Indonesia. Jurnal Bisnis dan Akuntansi Vol. 12, No. 2, Hal: 69-80.

10. Haykal, M.,2007, Analisis Peran dan Fungsi SKPD dalam Pengelolaan Keuangan Daerah serta Pengaruhnya terhadap Kinerja (Studi Kasus pada Pemkab Aceh Timur, Tesis, USU.

11. Mahsun, Mohamad. (2009). Pengukuran Kinerja Sektor Publik (3th ed). Yogyakarta: BPFE.

12. Mardiasmo, 2004, Akuntansi Sektor Publik. Edisi Pertama, Penerbit Andi Yogyakarta.

13. Matindas, R.(2002), Manajemen Sumber Daya Manusia, Lewat konsep ambisi, kenyataan dan Usaha, Edisi II Grafiti, Jakarta

14. Menteri Dalam Negeri, Peraturan Menteri Dalam Negeri (Permendagri) No 13 Tahun 2006 tentang Pedoman Pengelolaan Keuangan Daerah.

15. Menteri Dalam Negeri, Peraturan Menteri Dalam Negeri (Permendagri) No. 59/2007 tentang Perubahan Atas Permendagri No. 13/2006 tentang Pedoman Pengelolaan Keuangan Daerah.

16. Nawawi, Hadari H dan Martini HM. 2004. Kepemimpinan Yang Efektif, cetakan keempat. Gadjah Mada University Press. Yogyakarta.

17. Republik Indonesia, 2004. Undang-Undang Nomor 32 Tahun 2004 Tentang Pemerintahan Daerah. Direktorat Jenderal Otonomi Daerah, Jakarta.

18. Republik Indonesia, 2004. Undang-Undang Nomor 33 Tahun 2004 tentang Perimbangan Keuangan Antara Pemerintah Pusat Dan Pemerintahan Daerah. Direktorat Jenderal Otonomi Daerah, Jakarta

19. Republik Indonesia, 2005. Peraturan Pemerintah Nomor 58 Tahun 2005 Tentang Pengelolaan Keuangan Daerah.

20. Republik Indonesia, Peraturan Pemeintah No. 21 tahun 2004 tentang Rencana Kerja dan Anggaran Kementrian Negara/Lembaga.

21. Republik Indonesia, Peraturan Pemerintah No 58 tahun 2005 tentang Pengelolaan Keuangan Daerah.

22. Republik Indonesia, Peraturan Pemerintah No. 20 tahun 2004 tentang Rencana Kerja Pemerintah.

23. Republik Indonesia, Peraturan Pemerintah No. 24 tahun 2004 tentang Standar Akuntansi Pemerintahan (SAP). 
Cristian Hartanto et.al. Factors affecting the performance of financial administration officials of regional apparatus organizations at the government of Medan.

24. Republik Indonesia, Undang-undang RI No. 1 tahun 2004 tentang Perbendaharaan Negara.

25. Republik Indonesia, Undang-undang RI Nomor 17 tahun 2003, tentang Keuangan Negara.

26. Republik Indonesia, Undang-undang RI No. 15 tahun 2004 tentang Pemeriksanaan Pengelolaan dan Tanggung Jawab Keuangan Negara.

27. Ririn, D. dan Mardiasmo. 2004. "The Effect Of Relationship Between Budgetary Participation And Decentralization Structure On Managerial Performance Of Local Government Agencies: The Role Of Organizational Commitment As Intervening Variable. (Empirical Study On Municipality And Regencies in Yogyakarta Province)", SOSIOSAINS, 17 (4). Hal 655-674.

28. Situmeang, C., Erlina, Maksum, A., \& Supriana, T. (2018). Effect of corporate governance on cost of equity before and after International Financial Reporting Standard implementation. Junior Scientific Researcher, 4(1), 1-13.

29. Situmeang, C., \& HABIBI, M. R. "Governance Based on Cost Analysis (Unit Cost Analysis for Vocational Schools)". Journal of Arts and Humanities, 7(2), 2243. 2018.

30. Sugiyono. (2014). Metode Penelitian Pendidikan Pendekatan Kuantitatif, Kualitatif, dan R\&D. Bandung: Alfabeta.
31. Suhartono, Ehrmann; Solichin, Mochammad, 2007, Pengaruh Kejelasan Sasaran Anggaran terhadap Senjangan Anggaran Instansi Pemerintah Daerah dengan Komitmen Organisasi sebagai Pemoderasi, Jurnal Akuntansi dan Keuangan Sektor Publik, Vol. 08 No. 01, Jogjakarta.

32. Suranto AW, 2005. Komunikasi Perkantoran, Cetakan Pertama, Media Wacana Yogyakarta.

33. Tuasikal, A (2007), Pengaruh Pemahaman Sistem Akuntansi Pengelolaan Keuangan Daerah Terhadap Kinerja Organisasi Perangkat Daerah. Jurnal Akuntansi dan Keuangan Sektor Publik, Vol.08, No.01, Februari 2007.

34. Warisno. 2009. "Faktor-Faktor yang Mempengaruhi Kinerja Satuan Kerja Perangkat Daerah (SKPD) di Lingkungan Pemerintah Provinsi Jambi". Tesis. USU: Sumatera Utara.

How to cite this article: Cristian Hartanto, Iskandar Muda, Chandra Situmeang. Factors affecting the performance of financial administration officials of regional apparatus organizations at the government of Medan. International Journal of Research and Review. 2022; 9(2): 68-81. DOI: https://doi.org/10. 52403/ijrr.20220211 